\title{
The new replacement name Euafricana nom. nov. for the preoccupied genus Africana Ocaña \& Brito, 2015 (Cnidaria: Anthozoa: Scleractinia: Caryophylliidae)
}

\author{
Filippo Ceccolini ${ }^{13}$, Fabio Cianferoni ${ }^{2} 4^{*}$
}

(1) Zoology, "La Specola", Natural History Museum, University of Florence, Via Romana 17, I-50125 Florence, Italy (2) Research Institute on Terrestrial Ecosystems (IRET), National Research Council of Italy (CNR), Via Madonna del Piano 10, I-50019 Sesto Fiorentino (Florence), Italy

(3) ceccolinif@virgilio.it; https://orcid.org/0000-0002-1476-914X

(4) fabio.cianferoni@cnr.it; https://orcid.org/0000-0003-3170-0774

* Corresponding author

http://zoobank.org/A6261519-EAB4-4620-BDDD-08626D453CAF

\begin{abstract}
The genus name Euafricana Ceccolini \& Cianferoni nom. nov. is proposed to replace the name of the coral Africana Ocaña \& Brito, preoccupied by the nematode genus Africana Travossos, 1920. Euafricana wirtzi (Ocaña \& Brito, 2015) comb. nov. is also established.
\end{abstract}

Keywords: Cnidaria, Heterakidae, new combination, nomen novum

The genus name Africana was used twice in zoological nomenclature. Recently, Ocaña \& Brito in Ocaña et al. (2015: 60) established a new genus using this name to allocate the new species $A$. wirtzi. The latter is an anthozoan described through a single colony from Santiago island in Cape Verde archipelago; it is included in Caryophylliidae with a peculiar mix of characters that makes it different from the other genera of the family: the presence of a solid corallum joined to the septal junction arrangement and pali presence (see Cairns \& Kitahara, 2012; Ocaña et al., 2015). The name is currently accepted (Rees, 2021; WoRMS Editorial Board, 2021).

Unfortunately, the same name had already been used for a new nematode genus by Travossos (1920: 48) to transfer three species from the genus Heterakis Dujardin, 1844. The name Africana Travossos, 1920 is currently accepted within Ascaridomorpha Heterakidae, including 10 species parasites of amphibians and reptiles distributed in Africa and the Neotropical region (see Bouamer \& Morand, 2008; Ávila \& da Silva, 2009). Thus, the genus Africana Ocaña \& Brito is a junior homonym of the genus name Africana Travossos and, according to the ICZN (1999, Article 60), since no synonyms are available (see ICZN, 1999, Art. 60.3), it should be replaced with a new name.

\section{Replacement name}

Herein we propose the name Euafricana Ceccolini \& Cianferoni nom. nov. This genus is monotypic and consequently the only species Africana wirtzi Ocaña \& Brito, 2015 is its type species.

\section{Etymology}

The new name follows the original one, adding the prefix $e u$ - (from the greek $\varepsilon \tilde{v}=$ true) since this genus really 
includes only African species, while its senior homonym Africana Travossos, 1920 currently includes also some American species. The gender of the new name is feminine.

\section{Systematics}

Class ANTHOZOA Ehrenberg, 1834

Order SCLERACTINIA Bourne, 1900

Family CARYOPHYLLIIDAE Gray, 1847

Genus Euafricana Ceccolini \& Cianferoni nom. nov. Species Euafricana wirtzi (Ocaña \& Brito, 2015) comb. nov. = Africana wirtzi Ocaña \& Brito, 2015 (type species)

\section{References}

Ávila R.W., da Silva R.J. 2009 A new species of Africana (Nematoda: Heterakidae) from lizards of Southern Amazon, Brazil. Journal of Parasitology 95 (2): 1156-1158. https://doi.org/10.1645/GE-1949.1

Bouamer S., Morand S. 2008 Morphological phylogenetic analysis of the Africana genus (Nematoda: Heterakidae). Journal of Parasitology 94 (2): 481-486. https://doi.org/10.1645/GE-1222.1

Cairns S.D., Kitahara M.V. 2012 An illustrated key to the genera and subgenera of the Recent azooxan- thellate Scleractinia (Cnidaria, Anthozoa), with an attached glossary. Zookeys 227: 1-47. https:// doi.org/10.3897/zookeys.227.3612

ICZN (International Commission on Zoological Nomenclature) 1999 International Code of Zoological Nomenclature. Fourth edition, adopted by the International Union of Biological Sciences. International Trust for Zoological Nomenclature, c/o The Natural History Museum, London, $\mathrm{xxx}+306 \mathrm{pp}$.

Ocaña O., den Hartog J.C., Brito A., Morro L., Herrara R., Martin J., Ramos A., Ballesteros E., Bacallado J.J. 2015 A survey on Anthozoa and its habitats along the northwest African coast and some islands: new records, descriptions of new taxa and biogeographical, ecological and taxonomical comments. Part 1. Revista de la Academia Canaria de Ciencias 27: 9-66.

Rees T. (compiler) 2021 The Interim Register of Marine and Nonmarine Genera. Available from https:// www.irmng.org at VLIZ. [Accessed 7 June 2021]

Travassos L. 1920 Contribuicoes para o conhecimento da fauna helmintolojica brazileira. IX. Sobre as especies do genero Spinicauda n. g. Memórias do Instituto Oswaldo Cruz 12: 44-50.

WoRMS Editorial Board 2021 World register of marine species. Available from https:// www.marinespecies.org at VLIZ. [Accessed 5 July 2021] 